\title{
artículos
}

\section{Un ejemplo de postmodernidad cinematográfica: la estética del pastiche en Moulin Rouge (Baz Luhrmann, 20011}

Tatiana Aragón Paniagua

Universidad de Málaga

PALABRAS CLAVE: Iconografía/ Cine

\section{RESUMEN}

En este artículo comentamos y analizamos los recursos formales del film Moulin Rouge en función de su pertenencia a un discurso especificamente posmoderno, y en el que una estética propia de un lenguaje ajeno al cinematográfico-el del videoclip-se combina con los presupuestos propios del contemporáneo lenguaje de la posmodernidad, revelándose asi como un clarísimo ejemplo de ésta.

ABSTRACT

In this article we comment on and analyse the formal means of Moulin Rouge according to his inscription to a specifically postmodern speech, where an aesthetics not belonging to a cinematographic language - the videoclip- combine herself with the characteristics of the contemporary language of postmodernism, like a clear example of him.

Moulin Rouge "es una historia sobre la libertad, la belleza y la verdad, pero por encima de todo..., es una historia sobre el amor": el amor imposible entre Christian (Ewan McGregor), un poeta inglés que abandona su acomodado hogar para unirse en París a la "revolución bohemia", y la bella cortesana Satine (Nicole Kidman), la estrella del espectáculo más famoso y fascinante del París finisecular. Una confusión hará que ambos personajes se enamoren, y deban hacer frente a la ambición del Duque (Richard Roxburgh), el inversor del "Moulin Rouge", que exige al dueño y regente del local, Harold Zidler (Jim Broadbent), los servicios de su primera bailarina a cambio de mecenazgo económico. Así, Satine y Christian deben amarse en secreto, y mientras ella, obligada por las circunstancias, entretiene al Duque con zalamerías y falsas expectativas, Christian, arropado por toda una cuadrilla de artistas bohe-

* ARAGÓN PANIAGUA, Tatiana: "Un ejemplo de posmodernidad cinematográfica: la estética del pastiche en Moulin Rouge (Baz Luhrmann, 2001)", Boletín de Arte $n^{\circ} 28$, Departamento de Historia del Arte, Universidad de Málaga, 2007, págs. 451-477. 
mios -entre los que se halla el pintor Toulouse-Lautrec (John Leguizamo)- compone una pieza teatral que se estrenará en el Moulin Rouge para darle al salón la categoría de un auténtico teatro. Pero Satine debe cumplir su trabajo con el Duque, por lo que Christian tendrá que enfrentarse a los inevitables celos, y finalmente, las circunstancias obligarán a la bailarina a mentir al protagonista para evitar su asesinato a manos de aquél. A pesar de todo, no será la maldad de este personaje el que impida la unión de Satine y Christian, pues el malentendido se resolverá durante el estreno de la obra teatral, y el Duque se verá finalmente vencido por los ideales de la "revolución bohemia". Será el destino inexorable que persigue a la protagonista, enferma de tisis, el que pondrá dramático fin a esta historia de amor.

Moulin Rouge es la tercera película del polifacético Baz Luhrmann (Sidney, 1962)1, tras las también musicales El amor está en el aire (Strictly Ballroom, 1992) y Romeo y Julieta de William Shakespeare (William Shakespeare's Romeo and Juliet, 1996), con las que conforma la denominada "Trilogía de la Cortina Roja". En este caso, y como ya hiciera en su controvertida versión del clásico de Shakespeare, el realizador recurre descaradamente a la estética y al discurso propios del videoclip actual, obteniendo como resultado un frenético musical que aporta un campo, como veremos, más que abonado para el despliegue de todos los recursos propios de la sensibilidad y la poética posmodernas.

En primer lugar se advierte que el argumento es aparentemente sencillo: adapta como esquema narrativo una combinación del tradicional triángulo amoroso, la típica historia de amor fou (cuyo referente indiscutible se halla en "La dama de las camelias", de Alexandre Dumas hijo) y la clásica estructura de descenso a los infiernos, pues Christian, como el mitológico Orfeo (no olvidemos que el personaje es un poeta), se adentra en un mundo oscuro y vicioso -el infierno del "Moulin Rouge"para rescatar a Satine que, como Eurídice, vive prisionera en él ${ }^{2}$. Aunque tras esta historia de amor imposible subyace una lectura más profunda que convierte a Moulin Rouge en una desgarradora metáfora sobre la naturaleza del artista, sobre la imposibilidad de vivir y de amar en los seres que están condenados a dedicar su vida al espectáculo, lo cierto es que la narración y el contenido se supeditan a unos aspectos formales artificiosos, exagerados y tremendamente llamativos, poniéndose todos los mecanismos del lenguaje cinematográfico al servicio del relato, que no es sino la excusa perfecta para poner en marcha esta trepidante y espectacular máquina de

\footnotetext{
1 Además de realizador cinematográfico, Luhrmann es actor, músico y compositor (ha participado en la elaboración de varios discos recopilatorios, y cómo no, en las bandas sonoras de sus filmes), guionista, productor y director de teatro y ópera, destacando su versión para televisión de la ópera de Giacomo Puccini La Bohème (1990) que sería revivida en los escenarios neoyorquinos en 2002.

2 Para un análisis de esta estructura argumental en un contexto cinematográfico, vid. BALLÓ, J. y PÉREZ X.: La semilla inmortal. Barcelona, Anagrama, 1997, págs. 235-248.
} 
1: artículos Un ejemplo de postmodernidad cinematográfica...

soñar que es Moulin Rouge. Ya desde los títulos de crédito, que aparecen tras la original apertura de un telón teatral, se nos atrapa en su vitalidad desbordante y en su frenesí, y tras la breve introducción de Christian con la que arranca la película, los acontecimientos comienzan a sucederse de forma trepidante e imparable.

Escrupulosamente cuidada desde un punto de vista estético, todo en Moulín Rouge es puro exceso: los planos, los decorados, las canciones..., la hacen absolutamente arrolladora, y la dotan de una tremenda capacidad de seducción que conquista al espectador hasta subyugarlo, o lo agota hasta la extenuación. En la consecución de este poderoso efecto envolvente resulta esencial esa concepción frenética del ritmo y el movimiento que se obtiene a partir de recursos tan elaborados y sofisticados como la propia película. Recursos cuya efectividad a la hora de seducir al espectador ha quedado ya más que demostrada en el terreno del videoclip, un discurso absolutamente familiar para nosotros, y que tiene como objetivo fundamental, precisamente, conquistar al público al que va dirigido (el film levanta pasiones, sobre todo, entre los espectadores más juveniles) ${ }^{3}$. Y es que Moulin Rouge, sin renunciar por ello a su naturaleza fílmica, no es sino un monumental vídeo musical concebido para su estreno y visualización en salas cinematográficas, circunstancia que potencia en gran medida su gran fuerza de impacto, pues la pantalla doméstica carece de la potencia hipnótica y fascinadora que caracteriza a la pantalla fílmica.

De cualquier modo, la naturaleza desbordante y espectacular de nuestra película halla en el lenguaje del videoclip su forma de expresión más idónea, pues su finalidad principal, como ha quedado claro, es la de lograr esa estética del exceso, la artificiosidad y el frenesí que ha de dejarnos sin aliento, embriagar nuestros sentidos, y divertirnos y conmovernos a un tiempo. Todos los mecanismos del lenguaje audiovisual se concentran en ello: desde la propia configuración de los encuadres -recargados, asimétricos, descentrados- hasta la intervención fragmentadora del montaje -que dota al film de ese ritmo endiablado- pasando por los alucinados efectos lumínicos o los colores agresivos de su sofisticada estética pictoricista. Merece la pena detenernos sobre algunos de estos refinadísimos recursos formales que nos invitan a vivir la vorágine, la locura y la siniestra belleza del espectáculo fascinante, y a la vez infernal, de Moulin Rouge.

En primer lugar nos detendremos en los encuadres. Como ya comentábamos, aportan importantes efectos de movimiento y desenfreno claramente patentes, por ejemplo, en las escenas y secuencias de baile. En ellas, grandes planos gene-

3 Existe una gran proximidad entre los discursos del videoclip y la publicidad, pues aunque hay visibles diferencias entre un video musical y un anuncio, el objetivo de ambos es el de seducir a un hipotético consumirenclas entre un dor que, de un modo u otro, debe albergar el deseo de adquirir lo que tan fervorosamente se le está mos-
trando. Para una profundización en las aproximaciones y diferencias entre ambos medios vid. SEDEÑO trando. Para una profundización en las aproximaciones y diferencias entre ambos medios vid. SEDEN
VALDELLÓS, A. M.: Lenguaje del videoclip. Textos Mínimos, Universidad de Málaga, 2002, págs. 39-41. 
rales de los salones del "Moulin Rouge", que se presentan como espacios infinitos, llenos de bailarinas de cancán, luces y colores, ilustran la magia, la alegría desbordante, pero también la pesadilla y la naturaleza febril del local. En esa búsqueda deliberada de efectos de artificiosidad y recargamiento estéticos, al tiempo que la máxima sensación de dinamismo, ritmo trepidante, abigarramiento y desequilibrio, Moulin Rouge recurre en numerosas ocasiones al plano oblicuo (podemos verlo cuando los bohemios irrumpen en la buhardilla de Christian, o en el cancán de Zidler; una de las escenas, incluso, comienza con un plano del "Moulin Rouge" al revés). Este efecto se ve reforzado por el empleo sistemático de planos saturados de objetos, donde los motivos se amontonan sin orden ni concierto, dando lugar, la mayoría de las veces, a encuadres asimétricos y desequilibrados.

La artificiosidad puede verse también subrayada mediante el empleo de picados y contrapicados muy forzados y de gran fuerza expresiva, como el acentuadísimo picado sobre Satine encaramada a su columpio, bajo el cual hay un gran número de caballeros que parecen esperar a que ésta caiga, y que ilustra la capacidad de seducción y fascinación que la bailarina puede ejercer sobre los hombres. Se recurre también, en varias ocasiones, al plano cenital, sobre todo en las coreografías, en las que los bailarines, como en los musicales que en la década de los treinta popularizara Busby Berkeley, forman dibujos mediante sus disposiciones o el color de sus trajes. Finalmente, y siendo tan importante en este film la noción de fragmentación y, por ende, la escasa duración de los planos, es también muy frecuente el intercalado constante de éstos, a diferente escala, en una misma escena o secuencia: así, por ejemplo, durante el Tango de Roxanne, podemos ver, desde el primer plano del violinista, que produce una música desgarradora, o planos de conjunto de los bailarines, al plano general en que Christian, insignificante y solo, avanza lamentándose por la supuesta traición de la protagonista.

Pero el elemento que más y con mayor fuerza imprime al film ese carácter fragmentario es sin duda el montaje, que dota a la película de un ritmo desenfrenado. La sucesión de planos es casi frenética, sobre todo en las secuencias coreografiadas, por lo que se produce un efecto de artificialidad y estilización que, combinado con otros elementos (los encuadres torcidos, los movimientos de cámara, el ritmo de la música) aporta al film un fuerte carácter perturbador. A ello se une la complejidad y el desorden temporal con que se presenta el argumento: aunque la película se desarrolla básicamente en orden cronológico y se ve agilizada mediante elipsis, es la historia en el pasado que Christian nos relata desde el presente. Se estructura por tanto a través de una serie de flashbacks sucesivos que nos van mostrando las vivencias de este personaje y de Satine, y que se intercalan con las escenas de la miserable existencia de Christian, una vez que la bailarina ha desaparecido de su vida. $Y$ junto a estos continuos saltos en el tiempo, percibimos, en ciertas ocasiones, 
2: artículos Un ejemplo de postmodernidad cinematográfica...

una figura cinematográfica muy poco usual por el desconcierto que provoca: el flashforward. Éste se efectúa de modo totalmente estricto cuando, en el despacho de Zidler, el Duque exige a éste que le ceda a Satine en exclusividad, bajo la amenaza de arrebatarle la propiedad del "Moulin Rouge": la voz over del Duque dice "Satine será mía", al tiempo que se introduce uno de los planos que luego veremos en una escena posterior, en la que este personaje intenta forzar a la protagonista. Otro de estos efectos se observa tras la reprimenda de Zidler a Satine después de sorprenderla por primera vez con Christian. Tras ella, la protagonista se desmaya, pero antes, mediante encadenado, se introduce un plano que luego veremos en el desenlace, y en el que Satine, tras el éxito del estreno y su reconciliación con Christian, se desvanece por última vez a causa de su enfermedad. Este plano, preludio de la tragedia que está por venir, también se intercalaba, casi subliminalmente, cuando Satine salía a escena por primera vez sobre su columpio, al principio de la película.

Otro recurso perturbador que observamos en la película, aunque de forma algo discreta, es la alteración del orden cronológico del relato. Apenas se advierte, pero causa cierta sensación de extrañamiento. Se produce, por ejemplo, en la escena en que Zidler y el Duque negocian sobre Satine y el "Moulin Rouge". Antes de que ésta termine, se intercala un breve plano del regente anunciando a todos la próxima conversión del local en un teatro. Después continuará la escena en el despacho con ambos personajes, tras la cual, volveremos otra vez a la de Zidler hablándole a sus artistas de la función que se va a representar. También durante la "canción secreta de los amantes" que Christian compone para Satine, se produce un desorden temporal: en primer lugar, la secuencia comienza con los dos personajes reunidos en la pensión del protagonista; después, se intercalará esta escena con otra posterior en el tiempo, en la que ambos continúan asistiendo a los ensayos, y tras ésta, aparece de nuevo la escena anterior. Se trata de una secuencia de montaje, en la que se sucederán más escenas aún: de nuevo en los ensayos, una merienda campestre con el Duque para ocultar su amor, y otra vez en la pensión.

Incluso en un aspecto en principio tan poco trascendente como los enlaces entre planos, Moulin Rouge desprende un gran efectismo y sofisticación, pues hace uso de todos los tipos de transiciones con creatividad y originalidad -como los movimientos de barrido con los que se intercalan los planos en la escena de Spectacular Spectacular- e incluso efectúa cambios de planos por medio de la puesta en escena y el trucaje, siendo muy llamativas las transiciones mediante efectos digitales. En este sentido, destaca la "espectacular" y envolvente escena en que los bohemios tienen la visión del Hada Verde a causa de la absenta, y que enlaza con la de la primera visita al "Moulin Rouge" a través de una transición original y fantástica en forma de remolino que combina un encadenado con un efecto especial.

Otro de los recursos más usados en el film es el empleo del movimiento ace- 
lerado, que aparece sobre todo en las coreografías y a menudo combinado con el ralentí para obtener una gran artificiosidad: así bailan el Hada Verde, las bailarinas de cancán de Zidler, o los figurantes de Like a Virgin. En Spectacular Spectacular, Zidler se mueve de un lado a otro en cámara rápida y también los personajes cuando preparan los improvisados escenarios con los que pretenden sorprender al Duque, o cuando se miran entre ellos ante las preguntas de éste. Además, los violentos travellings hacia delante mediante trucaje que jalonan el film, se asimilan a la cámara rápida. Sin embargo, más frecuente que el empleo del movimiento acelerado, o de la combinación de éste con el ralentí, es el uso individualizado de este último. Hay muchos ejemplos: en ocasiones, los planos de Christian en el presente se toman en cámara lenta para incidir en su tristeza. Satine siempre se desvanece en cámara lenta, pues estos desmayos son premonitorios del destino trágico que le espera. Uno de los momentos en los que este recurso se usa con gran virtuosismo es el de la muerte de la bailarina, en su mayor parte, tratado en cámara lenta, y particularmente desgarrador es el plano en el que el público aplaude la función, ignorante del drama que se vive tras el telón. En menor medida, se recurre también al fotograma congelado (por ejemplo, cuando el protagonista, recién instalado en su pensión de Montmartre, se dispone a escribir sobre el amor y se da cuenta de que no puede porque nunca se ha enamorado) o al movimiento invertido, que aparece brevemente cuando Satine y Christian bailan antes del primer encuentro en el elefante. En ambos casos, y a pesar de que estos recursos suelen proporcionar efectos de contención y dilatación temporal, en Moulin Rouge suceden de una forma muy rápida, sin apenas dar descanso a la vista, y generando una profunda sensación de aceleramiento.

Este efecto se halla estrechamente relacionado con el ritmo y la cadencia. Ambos son muy fuertes en toda la película, aunque en algunos momentos llegarán a ser absolutamente desenfrenados, como cuando Toulouse y sus amigos invaden la habitación de Christian, las bailarinas del "Moulín Rouge" bailan el cancán de Zidler, o todos los personajes intentan encandilar al Duque con Spectacular Spectacular. Sin embargo, también hay lugar en Moulin Rouge para la dilatación temporal, destacando, en este sentido, la secuencia del Tango de Roxanne, en la que se alternan las escenas con Satine y el Duque en el torreón gótico, y la del baile de tango que ilustra la desazón del celoso Christian. La secuencia es un buen ejemplo de cómo la dilatación temporal se combina con el ritmo y la cadencia fuertes para crear efectos de ansiedad y suspense: además del empleo de la cámara lenta en ambas escenas (especialmente cuando el Duque, despechado por el rechazo de su amada, arranca del cuello de Satine el collar que le acaba de regalar), los planos del tango interrumpen constantemente los planos de la torre, de modo que la acción se contiene en este espacio mediante el montaje y la sucesión de planos, y por un momento dudamos, tras regalarle el Duque el collar, si la protagonista aceptará o no sus proposi- 
ciones. Finalmente, cuando Satine lo rechace, de nuevo mediante la sucesión de planos y la alternancia de éstos con el baile de tango, el tiempo en el que el Duque la maltrata se alarga enormemente, hasta que al fin irrumpe la presencia salvadora de Chocolat, y el ritmo se hace más relajado.

Pero quizá sea la puesta en escena el aspecto que más contribuye a la particular configuración estética de Moulin Rouge. Todo en ella es artificioso y recargado, proporcionando una estética kitsch y excesivamente adornada, que ilustra la sofisticación del local. Oscilando entre la fascinación y la magia, pero al mismo tiempo, entre la locura y el desasosiego. Los decorados, el atrezzo, la luz... imprimen al film una profunda sensación de ansiedad y desaliento provocada por la construcción de un espacio agobiante y viciado, donde las figuras, los objetos y los colores se amontonan sin orden ni concierto y se mueven de un lado a otro. De hecho, el "Moulin Rouge" es la prisión de Satine, y tras la sofisticación, el refinamiento y el desenfreno del gran espectáculo, late el drama y la tragedia de todas aquellas personas que como ella, son criaturas de la farándula, para quienes no hay otro destino que el de dedicar sus vidas al divertimento de los demás: por encima de ellas, y a toda costa, "el espectáculo debe continuar".

Como película rodada totalmente en interiores, destaca el uso sistemático de elaboradas maquetas de París y en concreto de Montmartre, para llevar a cabo las localizaciones generales, así como de grandes y aparatosos decorados que configuran diferentes ambientes. Estamos ante una sofisticada recreación de un lugar y una época concretos -el París de finales del siglo XIX- marcados por una profunda conciencia de decadencia ante el cambio de siglo, y estéticamente encabezado por los dandis y artistas bohemios, herederos directos del no muy lejano Romanticismo, que se veían a sí mismos como una élite, los únicos capaces de hallar la verdad y la belleza en un tiempo que ellos consideraban totalmente en crisis. Moulin Rouge capta el espíritu de este momento fascinante a través de su puesta en escena, que crea un entorno ideal para una película que quiere ser tan decadente y tan simbolista como la propia época que recrea.

Para ello, recurre a unos decorados y a un atrezzo que caen conscientemente en el más absoluto pastiche, fruto de una exageración recargada y ecléctica. Los más llamativos son los del "Moulin Rouge": el salón en el que Satine hace su primera aparición es un lugar de ensueño, lleno de cortinajes, palcos, lámparas de araña, tonos rojizos y dorados. Sin embargo, el ambiente más destacable es sin duda la alcoba de la protagonista, que adquiere la forma de un gran elefante 4 en cuyo interior se dispone el dormitorio; se trata de un espacio espectacular y casi increíble,

4 Elefante que se inspira en el enorme paquidermo de papel maché que, procedente de la reciente Exposición Universal de 1889, había sido dispuesto junto al escenario en el jardín del Moulin Rouge. Vid. FELBINGER, U.: Toulouse-Lautrec. Könemann, 1999, pág. 28. 


2: artículos Tatiana Aragón Paniagua

representativo de la sofisticación y extravagancia que puede llegar a ofrecer el "Moulin Rouge". En su interior confluyen elementos decorativos y arquitectónicos de todo tipo y de todos los estilos, entre los que destacan las referencias al arte japonés e indio, muy del gusto de los artistas decadentes de la época (por lo que su inclusión en la ambientación de esta película es ideal), y de especial relevancia en el argumento, que gira en torno a una representación teatral que se desarrolla en la exótica India. Muestra, por otra parte, como Satine, encerrada en esa fascinante prisión, es una más de las extravagantes exquisiteces que vende el burdel. También el torreón gótico, destinado a los encuentros entre Satine y el Duque, resulta muy llamativo, pues contribuye a proporcionar un inquietante y siniestro ambiente similar a los generados por el cine de terror. Igual efecto de recargamiento y estilización se observa en la concepción del vestuario, colorista y elaborado, y en el maquillaje, extremadamente marcado, como de payaso, pues eso es lo que son, al fin y al cabo, los personajes del espectáculo (Satine, en cambio, presenta un maquillaje neutro que la diferencia del resto de los personajes). Paradójicamente, el ritmo frenético con que discurre el film impide la visualización con calma y detalle de tan exquisita puesta en escena, cuya fuerza subliminal, sin embargo, no pasa desapercibida ante la retina del espectador.

También la fotografía y el color inciden en la fascinación y sordidez que rodean al burdel. Pero además, se emplean como importantes resortes dramáticos, intensificando las emociones, las sorpresas, y los sentimientos: Moulin Rouge es un puro "golpe" de efecto, tanto visual como psíquico. En primer lugar, podemos subrayar como se ha despreciado casi por completo el uso naturalista de la luz, optándose por una iluminación efectista, fantástica y artificiosa que genera una atmósfera irreal y espectacular, y en la que el tono alto y el tono bajo se alternan indistintamente según las necesidades dramáticas. Más llamativo y efectista aún es el uso que se hace del color, totalmente expresivo, y en la mayoría de los casos nada naturalista: tonos cálidos, anaranjados, dorados, brillantes, verdosos, violetas, y sobre todo rojos, ilustran las escenas y secuencias que tienen lugar dentro del "Moulin Rouge", que se presenta así como el lugar idóneo para la evasión y el abandono a los placeres más sofisticados. Estas escenas contrastan con los planos exteriores del local, siempre grisáceos o azulados, e incluso virados al sepia, como cuando al principio del film, Toulouse-Lautrec comienza a hablarnos de Christian mientras visualizamos planos del Moulin Rouge y de Montmartre en este tono, para denotar que se trata de un acontecimiento pasado y triste. Al mismo tiempo, se advierte también un uso simbólico del color, principalmente del rojo, asociado a conceptos como pasión, vida, o amor: rojo es el vestido de Satine, rojas son las luces del burdel, y en la escena en sepia que acabamos de describir, tras un violento travelling hacia delante a través de todo el barrio de Montmartre, sólo el letrero de la pensión que habita el protagonista aparece coloreado: ésta se llama, no por casualidad L'Amour fou, y las letras, cómo 


- E átículos Un ejemplo de postmodernidad cinematográfica...

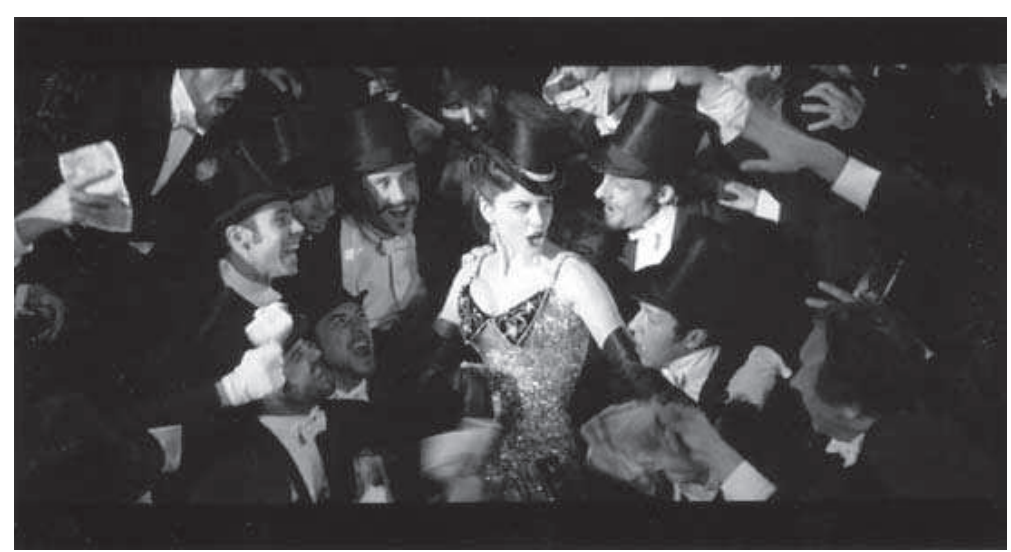

1. Satine, el "diamante reluciente" del "Moulin Rouge".

no, son rojas. De igual modo, cuando Zidler convence a Satine para que mienta a Christian, las luces rojas de las aspas del molino se proyectan sobre su rostro, al tiempo que giran, subrayando ambos la indisoluble vinculación de la protagonista al mundo del espectáculo.

Un ejemplo del exquisito y artificioso uso del color que hace el film lo podemos encontrar en la secuencia en que Christian, al no creer la mentira de Satine, vuelve al local durante el estreno de su propia obra: al mismo tiempo que oímos su voz over, "volví al 'Moulin Rouge' por última vez", observamos una sucesiva gradación de color, desde el negro y gris del exterior del local, hasta el rojo en su interior, culminando en la estridente explosión cromática que se produce en el escenario, exultante de gamas brillantes. Pero estos brillos se transforman en azules y violáceos con la aparición de Satine, no sólo para subrayar su importancia en la escenografía, sino también para incidir en la proximidad de la tragedia. Y es que Moulin Rouge está repleta de fogonazos, destellos, chispas de luz y golpes de iluminación, que en muchas ocasiones -y como no podía ser menos en una película tan "videoclipera" como ésta- al ritmo de la música, contribuyen a la consecución de este espacio mágico y vibrante.

A la hora de recrear la profundidad espacial, la película recurre más frecuentemente al foco selectivo combinado con la iluminación y la superposición de dife- 
rentes tonos de colores. Pero también hace uso de la profundidad de campo, que proporciona en ocasiones imágenes muy bellas, como la de los protagonistas abrazados ante el elefante enmarcados por los sucesivos corazones que conforman las puertas de esta extravagante estancia. O tan impactantes y atrayentes como las del interior del "Moulin Rouge" durante los bailes desenfrenados, en las que las numerosas bailarinas de cancán, con sus vestidos y sus movimientos, parecen configurar un espacio casi sin límites, infinito. En ambos casos se evidencia la naturaleza videoclipera de Moulin Rouge, pues la imagen videográfica no permite la coherencia espacial que en el cine sí se logra mediante la jerarquización del plano o la profundidad de campo, acercándose más a una imagen bidimensional, donde los motivos, más que disponerse, se yuxtaponen ${ }^{5}$. En la estética de nuestra película se advierten estas peculiaridades, pero a la vez, es posible evidenciar como éstas se producen, a veces, gracias al uso de recursos visuales específicamente cinematográficos, como es el caso ya comentado de la profundidad de campo, gracias a la cual se ofrecen planos saturados de personajes y objetos que se extienden hasta el infinito.

Pero si Moulin Rouge es una película movida y trepidante, lo es, sobre todo, en virtud a la combinación magistral entre el montaje y esta alucinada puesta en escena, destacando, en este contexto, los movimientos de cámara: constantes movimientos de reencuadre y seguimiento de los personajes, al frenético ritmo de la música, se combinan con la escasa duración de los planos, lo que imprime al film un fuerte dinamismo. Algunos movimientos, además, son poderosamente llamativos y llenos de expresividad, y hacen gala de una gran trascendencia dramática produciendo a veces atractivos e impactantes planos. Probablemente, los más originales sean los violentos travellings hacia delante y hacia atrás, a menudo combinados con grúa, y con cierto balanceo, que recorren en varias ocasiones todo el barrio de Montmartre gracias al trucaje y a las maquetas. Al comienzo de la película, uno de estos travellings nos introduce de forma violenta en el barrio más bohemio y decadente de París. También, durante el primer baile de cancán, uno de estos movimientos nos muestra a Zidler dando espectaculares volteretas mientras canta. Pero es en las diferentes coreografías donde se manifiesta con más claridad esa combinación de movimientos de cámara y montaje rápido que produce el gran dinamismo de la película. En las escenas de baile más desenfrenadas (el cancán, Spectacular Spectacular y Like a Virgin), los travellings en todas direcciones, rápidos o lentos, se combinan con panorámicas, balanceos y barridos. La cámara en mano, que hace que ciertos hechos resulten más cercanos y dramáticos para el espectador (como cuando Satine cae del columpio y es recogida al vuelo por Chocolat, que se la lleva en brazos ante la mirada curiosa de los espectadores), y por supuesto, el zoom (de cierre sobre

5 SEDEÑO VALDELLÓS, A. M.: Op. Cit., pág. 14. 
Christian cuando ve caer a Satine del columpio, o cuando espera impaciente a ésta en el elefante; o el zoom de apertura sobre los bohemios bailando en la cornisa de L'Amour fou tras la aparición del Hada Verde) no podían faltar en la estética "videoclipera" de nuestra película.

Sin embargo, el aspecto más llamativo de Moulin Rouge es su particular banda sonora. Tratándose de una película musical que adopta el discurso del videoclip, es evidente que aquélla debe responder, forzosamente, a un tratamiento especial: si obviamos el discreto y empático reforzamiento musical de fondo (melodía circense cuando los bohemios arrasan el cuarto de Christian, música de tango cuando toma protagonismo el Argentino, etc.), lo verdaderamente interesante en este film son las diferentes canciones con las que se expresan los personajes y que conforman la mayor parte de la banda sonora. Algunas, como Diamonds are a Girl's Best Friend, el cancán de Zidler o Hindi Sad Diamonds forman parte del espectáculo que ofrece el "Moulin Rouge", pero la mayoría son canciones que surgen espontáneamente como particular forma de expresión de los protagonistas.

Las canciones, grandes hits de la música pop de la segunda mitad del siglo $X X$, llevan a cabo una función igualmente empática, pero lo realmente destacable es, obviamente, el brutal anacronismo que suponen con respecto a la época recreada: All you need is Love, del álbum de The Beatles "Magical Mistery Tour"; Your Song, uno de los primeros éxitos de Elton John; Lady Marmelade. Voulez-vous couchez avec moi? de Labelle; Diamond Dogs y Heroes de David Bowie; Silly Love Songs, compuesta por Paul McCartney ya en solitario; I will Always Love You, de Dolly Parton, reversionada en los noventa por Whitney Houston para El guardaespaldas (The Bodyguard, Mick Jackson, 1992); Roxanne, de The Police; Rythm of the Night, de Thelma Houston; I Was Made for Loving you, de Kiss; Rythm of the Night; Up where we belong, tema principal de Oficial y caballero (An Officer and a Gentleman, Taylor Hackford, 1982), e interpretada por Joe Cocker y Jeniffer Warnes; Material Girl y Like a Virgin, del álbum más polémico de Madonna; One Day I'll Fly Away, popularizada por Randy Crawford; One More Night, de Phill Collins; Pride (in the Name of Love) de U2; The Show must go on, de Queen; o Smeels Like Teen Spirits, de Nirvana.

Junto a éstas, se recuperan clásicos como el de Nat King Cole Nature Boy, de gran repercusión a finales de los cuarenta, o, aunque cantada en inglés, la balada Complainte de la butte, compuesta por Georges Van Parys pero escrita por Jean Renoir para su film French can can (1955). Algunos de ellos son objeto de divertidas versiones, como las operetas de Offenbach Orphee aux enfers (1858) y Voyage dans la lune (1875), así como Gaîte parisienne (ballet compuesto por Manuel Rosenthal en 1953, inspirado en diferentes temas de Offenbach y basado a su vez en la partitura que Etienne de Beaumont creó en 1938 para un ballet de Leonid 


- a atículos Tatiana Aragón Paniagua

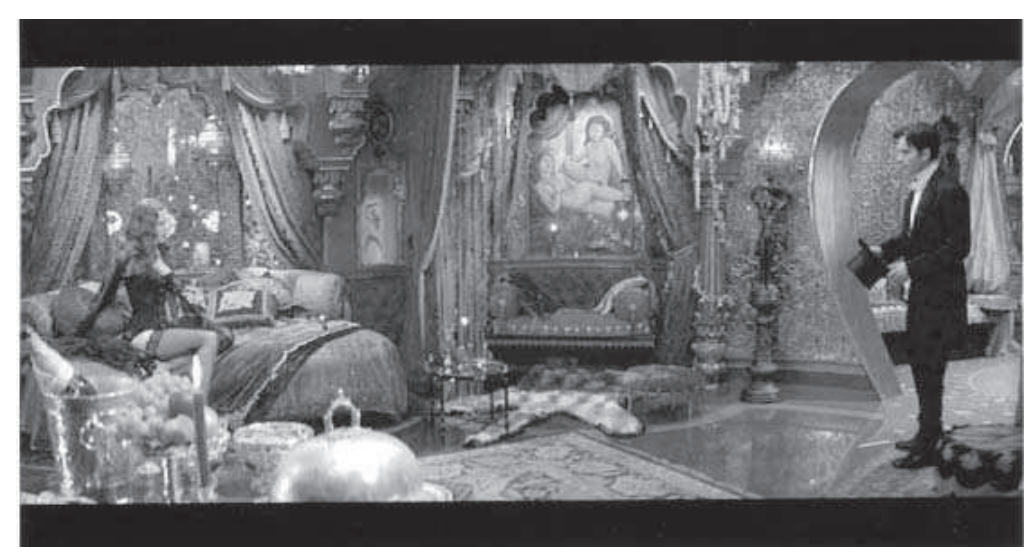

2. Un ejemplo de la sofisticación y recargamiento estéticos de Moulin Rouge: la estancia de Satine.

Massin). Especial protagonismo adquiere el tema que Marilyn Monroe inmortalizó en Los caballeros las prefieren rubias (Gentlemen prefer Blondes, Howard Hawks, 1953) Diamonds are a Girl's Best Friend, y que ilustra la aparición espectacular de la estrella del Moulin Rouge, contribuyendo a crear una falsa impresión de ella, y con una relevancia dramática mucho más importante de lo que parece: el Duque tentará a Satine con riquezas y joyas, pero ésta nunca se dejará seducir por ellas. Esta famosa declaración de principios popularizada por Marilyn, no comulga en absoluto con las verdaderos pensamientos de nuestra protagonista. Junto al anterior, el tema principal de Sonrisas y lágrimas (The Sound of Music, Robert Wise, 1965), con letra de Oscar Hammerstein y música de Richard Rodgers, cobra igualmente un interés especial, actuando como leitmotiv en diversos momentos del film.

Aunque menos importantes, en la banda sonora de Moulin Rouge también destacan los efectos o ruidos, tratados de un modo muy creativo y original. Algunos de ellos son diegéticos, pero se exageran y estilizan pare darles ese toque de artificiosidad tan característico del film. En este sentido, podemos destacar el sonido que producen las aspas del "Moulin Rouge", como si éstas, al girar, cortaran el viento: este ruido acompaña a todos los planos generales en los que aparece el burdel, reforzando su carácter amenazante, como símbolo del destino de Satine. Efectos similares acompañan a los movimientos de la protagonista cuando se produce la confusión entre el Duque y Christian: la propia Satine produce este particular sonido al levantar- 
se de la cama o al arrojar a los otros personajes sobre ella, obteniéndose así un efecto sonoro muy cómico en consonancia con la escena. También los bohemios, que la están observando desde fuera, producen este sonido al mirarse unos a otros y al esconderse. Son sonidos creíbles, puesto que vemos la fuente de donde proceden, pero al exagerarse, pierden cualquier carácter realista o naturalista, y se convierten en elementos eminentemente expresivos. En cuanto a los sonidos no diegéticos, podemos destacar el efecto sonoro que acompaña a esos travellings tan violentos que recorren todo Montmartre a lo largo de la película: en este caso (y como viene siendo habitual en el cine comercial contemporáneo), sí que es un sonido totalmente artificial, pues en teoría, lo produce la cámara al avanzar o retroceder muy rápidamente. De nuevo, parece como si se cortara el viento, y el efecto contribuye a evidenciar el propio carácter ficticio del que la película es consciente en todo momento, ya que al ser producido por el movimiento de la cámara no provendría de la película en sí, sino de su elaboración técnica como tal, y no debería, por tanto, ser percibido por el espectador.

La divertida aparición del Hada Verde (una inspirada Kylie Minogue) supone la introducción en el film de un discurso más, el de los dibujos animados ${ }^{6}$. Éstos, junto a otros efectos digitales o infógráficos, son muy frecuentes en los videoclips para liberar la imagen de una objetividad excesiva, haciéndola más seductora y proporcionándole un carácter más informal, humorístico o anecdótico ${ }^{7}$. La alucinación que sufren los bohemios cuando ingieren la absenta antes de llevar a Christian al "Moulin Rouge" lo ejemplifica: obnubilados por la bebida, los personajes contemplan como el hada que aparecía pintada en la etiqueta de la botella, les hace un guiño y se "escapa" de ella, entonando la canción The Sound of music, y multiplicándose hasta formar un coro de vedettes. Una fotografía de color verdoso, que es el color de la absenta, marca la diferencia entre la realidad y esta alucinación que termina con una especie de remolino fantástico que engulle a los personajes. También la luna (cuya voz pertenece mi más ni menos que a Plácido Domingo), que acompaña a los protagonistas con un solo de ópera en Your Song y en la escena de las canciones de amor sobre el elefante, se halla caracterizada con facciones humanas ojos, nariz y boca- y gesticula divertidamente mientras canta, en claro homenaje al cine Georges Méliès.

Y es que, como ya hemos comentado, Moulin Rouge se erige como un auténtico videoclip, prácticamente desde que empieza hasta que acaba, pues no hay que esperar a que aparezcan las escenas cantadas y bailadas para que se desplieguen

${ }^{6}$ En realidad, el Hada Verde no es un dibujo animado, sino una actriz real. Sin embargo, su configuración imita deliberadamente, mediante un efecto especial, la estética de éste.

7 SEDEÑO VALDELLÓS, A. M.: Op. Cit., pág. 52. 
los recursos propios del lenguaje del vídeo musical: todo en este film remite a las técnicas y estrategias formales propias de este discurso ${ }^{8}$. Para empezar, la excelente calidad fotográfica con que está filmado y el uso exprexivo del color ya nos remite, de forma directa, a este medio. También es constante en el videoclip el empleo de tonalidades irreales y fuertes contrastes, quizá el aspecto más destacable de la fotografía de Moulin Rouge, siendo igualmente frecuente el inserto de elementos que tienen un valor emocional destacado, fuertemente coloreados, sobre fondos en blanco y negro (ya hemos comentado como el significativo nombre de la pensión donde vive Christian, L'Amour Fou, se destaca en intenso color rojo sobre un fondo, en este caso, virado al sepia).

Por otra parte, como ya comentábamos, en el videoclip desaparece la profundidad perspectívica, y los planos, que se yuxtaponen y superponen frenéticamente al ritmo de la música, son desestructurados y descentrados, con varios focos de atención, ya que las figuras que lo conforman entran y salen de él incesantemente, al ritmo de los golpes lumínicos. Y es que, entre los recursos de iluminación más característicos del vídeo musical, se halla el uso del flash de luz como forma de desestabilización, un efecto que Moulin Rouge explora y lleva a la práctica, como hemos visto, de un modo verdaderamente sorprendente. $\mathrm{Y}$ si algo es característico en el videoclip, son los efectos visuales, que permiten, entre otras cosas, la aparición y desaparición sorpresiva de objetos, su multiplicación, y la ubicuidad de los personajes que, como Satine y Christian en la secuencia de la "canción secreta", no están sujetos a coordenadas espacio-temporales, lo que permite la simultaneidad de escenas y la creación de entornos ficticios (algo, por otra parte, bastante frecuente en el musical clásico americano). Las transiciones espectaculares mediante efectos visuales, como el remolino que arrastra a los bohemios al Moulin Rouge después de beber la absenta, son muy usadas para acentuar la propia retórica de espectacularidad del medio. Pero el gran protagonista es el ritmo de la música (en el caso de nuestra película, además, una música muy especial, y cómo no, muy "videoclipera"), que determina el discurso y contribuye igualmente a que los parámetros espacio-temporales no tengan que doblegarse a las leyes de la coherencia. Debemos tener en cuenta que, desde el punto de vista de la temporalidad, el videoclip presenta todas las velocidades, pero opta por la celeridad y el ritmo frenético, y gusta combinarlos con el ralentí, lo que aporta heterogeneidad, condensación y fragmentación, efectos que Moulin Rouge obtiene con gran maestría, especialmente en las escenas coreografiadas.

Por otra parte, el videoclip no suele desplegar un dispositivo narrativo -además, no es el medio más idóneo para hacerlo- y opta en cambio por uno descriptivo,

8 Para una profundización en los rasgos y características específicos del discurso del videoclip, vid. DURÁ, R.: Los videoclips: precedentes, orígenes y características. Valencia, Universidad Politécnica, 1988. 
2: artículos Un ejemplo de postmodernidad cinematográfica...

de modo que cuando existe un argumento, éste se condensa y simplifica para que todo el protagonismo recaiga sobre los aspectos formales del discurso. $Y$ después de todo, ¿qué es Moulin Rouge sino un refinado y sofisticado envoltorio que relata por enésima vez la más manida historia de amor? La sofisticación es probablemente la clave para entender este film, cuya razón de ser radica en su propia existencia como dispositivo formal de gran fuerza sensorial. Es el juguete caro y extravagante que todos hemos deseado poseer, pero que en realidad, no sirve absolutamente para nada, salvo para el auto-goce de nuestra mirada subyugada, o como dirían Juan Miguel Company y José Javier Marzal, de nuestra "mirada cautiva" 9 . De hecho, para muchos, como advierte Román Gubern, el terreno del video musical es el más idóneo para la creatividad y experimentación audiovisual, puesto que, al no depender de una estructura narrativa (o al menos, no en gran medida) ofrece la posibilidad de desplegar en él los más vanguardistas recursos cinematográficos: la ausencia de raccord, el contraste cromático más violento, las elipsis más abruptas o el montaje más agresivo. Pero su finalidad no es otra que la de producir en el espectador un efecto hipnótico que refuerce su deseo consumista (ya hemos hablado de la cercanía de este discurso al de la publicidad), lo que entra en fuerte contradicción con ese espíritu tan formalmente transgresor ${ }^{10}$. En este sentido, debe valorarse en el film de Luhrmann la ausencia de esa instancia al consumismo, siendo como es un film puramente gratuito, en el que no falta ese carácter hipnótico, no, pero en el que no hay más objetivo que el de erigirse, él mismo, en un monumental divertimento de artificiosidad y sofisticación.

Y es que quizá sea el gusto por la exageración, lo excesivo y lo afectado lo más significativo de Moulin Rouge, una película que, al fin y al cabo, se inspira en hechos, personajes y lugares que, desprovistos de la exageración y el exceso con que la película los "disfraza", existieron realmente: el "Moulin Rouge" fue un famoso salón de baile parisino inaugurado en 1889, siendo dirigido por el empresario Charles Zidler. Allí se reunían los pintores, artistas y escritores del mundo bohemio de fines del siglo XIX, destacando la presencia de Toulouse-Lautrec, que halló en este ambiente un lugar idóneo de inspiración para su obra. De hecho, los personajes de Zidler (que aparece con el nombre de Harold, en lugar de Charles) y de Toulouse, junto con el bailarín Chocolat, protagonista de algunos de los carteles del pintor, y del célebre músico Eric Satie, aparecen como secundarios junto a los sí ficticios Satine y Christian, pero como ya decíamos, sometidos a un proceso de estilización y exageración (gracias al vestuario, el maquillaje y la propia actuación de los actores), que

9 COMPANY, J. M. y MARZAL, J. J.: La mirada cautiva. Formas de ver en el cine contemporáneo. Valencia, COMPAI

10 GUBERN, R.: "El cine después del cine", en AA.VV.: Historia general del cine. El cine en la era del audiovisual. Vol. XII, Madrid, Cátedra, 1995, págs. 292-293. 
los convierte en personajes afectados, antinaturales y caricaturescos.

Por otra parte, siendo Moulin Rouge un film que quiere ser tan decadente como la propia época que recrea, es natural que una de sus principales fuentes de inspiración sea el estilo pictórico de las poéticas del Fin de Siglo ${ }^{11}$, especialmente, el simbolismo decadente: es imposible, contemplar Moulin Rouge, y no visualizar en nuestra mente las ensoñaciones de pintores como Gustave Moreau u Odilon Redon. Pero tampoco podían faltar en esta película las referencias a la obra de ToulouseLautrec: el despacho de Zidler aparece decorado con carteles publicitarios del "Moulin Rouge" que imitan directamente el estilo de este pintor.

Y junto a esa sofisticación que nos seduce y sublima, se despliega otro de los más característicos rasgos del videoclip: la artificiosidad, otro aspecto que Moulin Rouge lleva hasta el límite al hacerlo voluntariamente visible: el ambiente, los personajes, los decorados... todo es llamativamente falso, y la película se propone en todo momento que no olvidemos su carácter de ficción. A ello contribuye igualmente el telón que abre y cierra la película, que además se halla plagada de detalles que ponen constantemente de manifiesto su carácter irreal: los veloces e imposibles travellings por Montmartre; los sonidos efectistas y excesivos; la iluminación espontánea de todo París al entonar Christian Your Song; la luna que canta junto a los protagonistas; la pistola del Duque que, al ser golpeado por Zidler, sale disparada y rebota contra la Torre Eiffel; los fogonazos y destellos... Moulin Rouge es una película que no pretende parecer real, y llama la atención constantemente sobre su propia naturaleza ficticia, destruyendo el efecto de verosimilitud y revelando descaradamente los signos de la enunciación cinematográfica.

Sin embargo, la fuerza y la desmesura de Moulin Rouge no terminan aquí. Mucha de su capacidad de seducción radica, sobre todo, en el particular modo con que el film apela a la complicidad de un espectador que, además de sentirse subyugado y arrastrado por el exceso y la artificiosidad de la película, encuentra en ella una particular satisfacción de sus expectativas más "nostálgicas". Y el género al que pertenece nuestro film -el musical- es particularmente responsable de ello, pues ha sido, desde los propios inicios del cine sonoro, uno de los más queridos por Hollywood, que lo adoptó desde un principio como expresión perfecta del amor y la alegría de vivir, así como vehículo idóneo de escapismo y evasión. Concebido siempre como

11 Debemos tener en cuenta que, cómo advierten Áurea Ortiz y María Jesús Piqueras, "La pintura es la principal fuente visual de información para cualquier cineasta que intenta poner en imágenes el pasado. El lugar de donde extraer cómo vestían, cómo se peinaban, cómo eran las casas y los rostros de nuestros antepasados; en términos cinematográficos, lo necesario para elaborar vestuario atrezzo y caracterización [...] extraer conclusiones sobre cómo "se movían", o cuales eran sus gestos [...] establecer una gama cromática determinada o una forma de iluminación, siguiendo las características plásticas de un pintor, una escuela o una época". ORTIZ, Á. y PIQUERAS, M. J.: La pintura en el cine. Cuestiones de representación visual. Paidós, Barcelona, 1995, pág. 49. 


\section{Q artículos Un ejemplo de postmodernidad cinematográfica...}

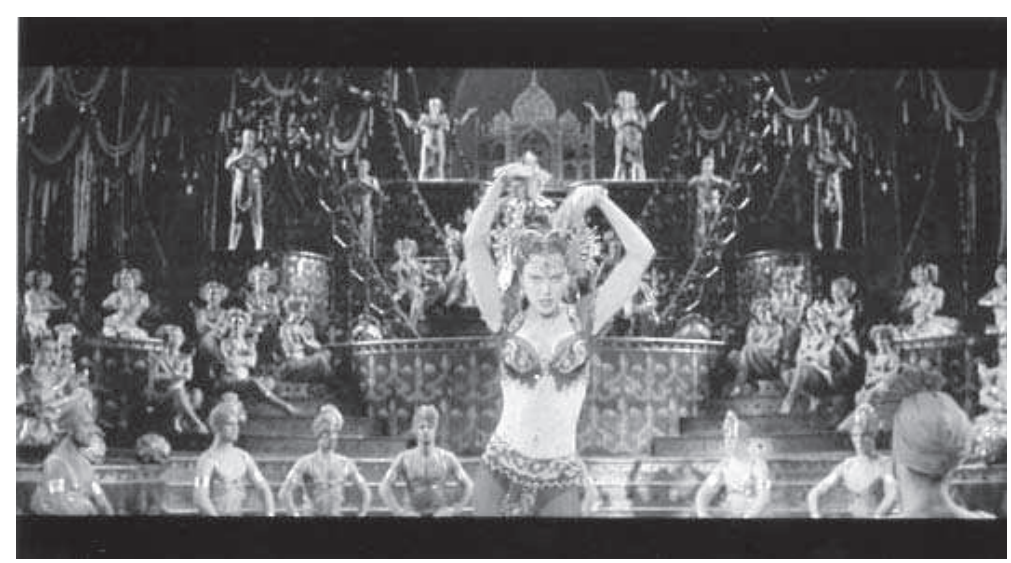

3. Un homenaje al cine de Bollywood: el número musical Hindi Sad Diamonds.

un gran campo de experimentación y fantasía, en el que el naturalismo y el realismo son superados por la magia de la música y la danza, el género experimentará una evolución constante, aunque nunca perderá, como así atestigua la propia Moulin Rouge, su carácter sublimador de la imaginación, la poesía y, sobre todo, del sentido del espectáculo ${ }^{12}$. En la actualidad, tras múltiples exploraciones temáticas y formales, el musical parecía haberse estancado y llegado a un callejón sin salida, pero la fantasía posmoderna de nuestra película demuestra las enormes posibilidades expresivas y experimentales que, desde su nacimiento, han caracterizado al género. Ante la supuesta imposibilidad de continuar innovando, tanto en lenguaje como en contenido, Moulin Rouge vuelve a mirar hacia el pasado, pero actualiza el género recurriendo al videoclip como forma de expresión, logrando así su revitalización.

De este modo, los grandes espectáculos que ofrece el "Moulin Rouge", como el número final Hindi Sad Diamonds, en el que multitud de bailarines llevan a cabo complicadas coreografías y forman composiciones caleidoscópicas que vemos a través de planos cenitales, aluden directamente a las películas que realizó Busby Berkeley durante la década de los treinta, y recrean el estilo de exageración y extravagancia inspirado en el music-hall característico de este director y gran coreógrafo.

12 Para un acercamiento al género puede verse SANTOS FONTENLA, C.: El musical americano. Madrid, Akal, 1973. 
En otras ocasiones, como en la secuencia de Like a Virgin que ya comentamos con anterioridad, los sirvientes del torreón gótico bailan al ritmo de la canción de Zidler y el Duque conformando iguales composiciones geométricas. Pero en esta escena el estilo de Berkeley, en cuyas películas los números musicales se desarrollan siempre como parte de un espectáculo integrado en la misma, se combina ya con otro tipo de cine musical, en el que las canciones y los bailes formaban parte de la acción del propio film, convirtiéndose en el particular y espontáneo modo de expresión de los personajes. Sin embargo, los musicales que más gozaban de esta espontaneidad y "magia", al formar parte sus bailes del mismo argumento de la película, eran los protagonizados por los inolvidables Fred Astaire y Ginger Rogers, a quienes Satine y Christian emulan cuando bailan al ritmo de Your Song. La figura de Gene Kelly es igualmente homenajeada por el protagonista, que baila sobre las nubes con un paraguas y bajo una lluvia de confeti, emulando al célebre bailarín cuando se encarama a una farola, sólo que en esta ocasión, ésta es sustituida por la punta de la Torre Eiffel.

Pero son más los recursos con los que Moulin Rouge apela a nuestra faceta más sentimental. Así, por ejemplo, y junto a esa entrañable -por familiar- banda sonora, capaz de emocionar al espectador más reticente, esos colores intensos que caracterizan a la película, obtenidos a partir de una fotografía sumamente estilizada y artificiosa, nos recuerdan al uso no menos exagerado y particularmente expresivo que, en su afán por estilizar la realidad y subrayar su carácter de espectáculo, hizo el musical del technicolor. Moulin Rouge recurre a ello, pero sin emplear este sistema, con iguales fines estéticos de estilización y sofisticación. Recordemos también como la película emplea elaboradas maquetas y decorados, lo que supone un bellísimo homenaje al cine clásico realizado en estudios. Pero probablemente sea el uso sistemático de la cita ${ }^{13}$ a grandes películas de la Historia del Cine, musicales o no, y que pertenecen a nuestro inconsciente colectivo y a nuestra cultura cinematográfica, la estrategia que más y mejor define la naturaleza nostálgica de Moulin Rouge ${ }^{14}$.

Entre los musicales homenajeados por nuestro film destaca Sonrisas y lágrimas, cuyo tema principal funciona, como ya dijimos, a modo de leitmotiv. con él dan comienzo los títulos de crédito, está presente en la obra que los bohemios ensayaban cuando conocen a Christian (y cuya acción se desarrolla en los Alpes, interpre-

13 Para Vicente Sánchez-Biosca, "la forma en que vive en nuestro discurso contemporáneo la palabra de los otros". SÁNCHEZ-BIOSCA, V.: Una cultura de la fragmentación. Pastiche, relato y cuerpo en el cine y la televisión. Valencia, Filmoteca de la Generalitat, 1995, pág. 18

14 En el marco cultural de la posmodernidad, afirma Manuel Palacio, el espectador es protagonista de nuevos modos de recepción e interpretación de los textos, pues la intertextualidad que caracteriza al mensaje posmoderno exige a aquél ser partícipe de la misma y desarrollar para ello unas ciertas técnicas de lectura que tienen como objetivo completar el texto dado o, cuanto menos, participar en él para completarlo. PALA CIO, M.: "La noción de espectador en el cine contemporáneo", en AA.VV.: Historia general del cine. El cine 
tando Toulouse el papel de una monja), el Hada Verde la canta en su alucinación, y vuelve a aparecer en medio del cancán de Offenbach en Spectacular Spectacular. El recuerdo a Cantando bajo la lluvia (Singin'in the Rain, Stanley Donen y Gene Kelly, 1952), no podía faltar: como ya hemos comentado, cuando Christian entona Your Song, baila con un paraguas bajo una lluvia de confeti, y emula a Gene Kelly encaramándose a la punta de la Torre Eiffel.

Pero son muchas más las grandes películas homenajeadas por Moulin Rouge: la famosa grúa ascendente que en Ciudadano Kane (Citizen Kane, Orson Welles, 1940) ilustraba la ridícula actuación operística de Susan Alexander, enfocando a dos tramoyistas que, sobre el escenario, ponen en entredicho con sus gestos la dudosa competencia de la cantante, es recreada en el momento en que muere Satine. Pero esta vez los tramoyistas lloran desconsolados la muerte de la protagonista. Por otra parte, la estancia del torreón gótico se asemeja, con su gran chimenea, a la gran sala de Xanadú donde languidecía la esposa de Kane. También son varias las escenas que evocan Lo que el viento se llevó (Gone With the Wind, Victor Fleming, 1939): como Escarlata, Satine hace a su ama ajustarle el corsé cuando se prepara para su encuentro con el Duque, y el plano en que los protagonistas se besan, tras Your Song, justo antes de descubrirse la verdadera identidad de Christian, se asemeja extraordinariamente a la escena en que Rhett Butler se despide de Escarlata tras sacarla de la ciudad sitiada, aunque en Moulin Rouge los tonos rojizos de Atlanta en llamas son sustituidos por las luces del local. En otra ocasión, cuando Satine canta One Day I'll Fly Away, en un plano muy breve, su silueta totalmente a contraluz ante las luces rojizas del "Moulin Rouge" de fondo, recuerdan el momento en que Escarlata jura no volver a pasar hambre, al regresar a Tara arrasada por los yanquis.

Pero además, Satine se quita el guante como Gilda (Charles Vidor, 1946) a mitad de Diamonds are a Girl's Best Friend, y las primeras imágenes del espectáculo del "Moulin Rouge", durante el cancán de Zidler, con esos personajes tan extravagantes (una bailarina enana, otra inmensamente gorda, una encantadora de serpientes, una sirena...), nos recuerdan a los protagonistas de La parada de los monstruos (Freaks, Tod Browning, 1932), e incluso la estancia se parece bastante a la sala de fiestas de El Ángel Azul (Der blaue Engel, Josef Von Sternberg, 1930), sobre todo, si nos fijamos en la indumentaria de la bailarina principal: como Lola-Lola (Marlene Dietrich), Satine viste un provocativo corpiño y una gran chistera.

Por otra parte, los numerosos chispazos y fogonazos que jalonan la película,

en la era del audiovisual, op. cit., pág. 75. En este contexto se despliegan las innumerables citas que campan en los distintos discursos contemporáneos, y que buscan, indudablemente, la complicidad de un espectador que alberga en su memoria visual las claves para la interpretación de las mismas dentro del texto en el que éstas aparecen integradas. 
a veces dando aparición a un personaje como por arte de magia (como en la función final, cuando surge en el escenario el marajá encarnado por Zidler), nos recuerdan al primitivo cine de atracciones de principios de siglo (y contemporáneo, por cierto, a la época que recrea la película), y algunos planos en concreto (la luna que canta, las minúsculas figuras de los bohemios, que se encaraman al elefante para espiar a los protagonistas) aluden directamente al cine de Georges Méliès. El Hada Verde, que aparece ante los protagonistas cuando éstos beben la absenta, es un trasunto de la Campanilla de Peter Pan, en especial en su versión de Disney (Hamilton Luke, 1953), y atrapa a los personajes para conducirlos al fascinante mundo del "Moulin Rouge", en un remolino semejante al que transportara a Dorita a la mágica tierra de Oz en El mago de Oz (The Wizard of Oz, Vitor Fleming, 1939). Ya hemos comentado como la canción Complainte de la Butte pertenecía a French Can Can, pero Jean Renoir también es homenajeado a través de una de sus películas menos reconocidas, La carroza de oro (Le Carrosse d'or, 1952), cuyo argumento -una fábula sobre la imposibilidad de compaginar la vida y el teatro- Moulin Rouge recrea.

Una cita más refinada supone la mención que Satine hace sobre la actriz Sarah Bernhard, a quien admira, y a quien le gustaría emular cuando se cumpliera su deseo de abandonar el local y convertirse en una auténtica actriz. La cartela con que da comienzo la película ("París: 1900") es igual a las que se empleaban en el cine mudo, así como el efecto de reserva con que vemos a Tolouse-Lautrec cantando Nature Boy. La presencia de David Wark Griffith tampoco falta en este homenaje: el plano en que Satine, ya consciente de su enfermedad, llora tras la imagen difuminada de un pájaro enjaulado ya aparecía en El nacimiento de una nación (The Birth of a Nation, David Wark Griffith, 1915) con idéntico sentido, pues ilustraba la desazón de la cautiva protagonista. Finalmente, advertimos también el particular homenaje que el propio realizador se dedica a sí mismo en la secuencia de Your Song: Satine y Christian bailan rodeados por una puesta en escena muy parecida a la que enmarcaba una de las coreografías principales de El amor está en el aire, la primera película de Luhrmann.

Así, vemos como Moulin Rouge recurre descaradamente a la reelaboración, al recuerdo, a la cita, y en definitiva, al pastiche, por medio de la utilización de un patrimonio cinematográfico preexistente. Éste es reciclado y revitalizado a través de su recreación combinada con un discurso tan radicalmente contemporáneo como es el del actual videoclip. Por ello, y a pesar de su fuerte carácter nostálgico, la repetición de lo ya elaborado presenta, en este caso, una gran fuerza innovadora que se basa en la disposición de estos motivos en un nuevo contexto. Paradójicamente, la renovación viene determinada por un material de "segunda mano", cuyo especial tratamiento permite frenar el declive al que el género del musical parecía estar condenado. Este comportamiento responde a una de las inquietudes que más preocupan 
a nuestra propia sensibilidad posmoderna, pues las grandes ficciones y relatos míticos que hasta ahora han sido elementos constitutivos y sustentantes de nuestra cultura, sufren en el contexto de la posmodernidad un proceso de desintegración ${ }^{15}$ que trae consigo una fragmentación inevitable y perceptible en todos los niveles del pensamiento humano. Entre otras consecuencias, ésto da lugar a la continua revisitación nostálgica de esa realidad anterior a la fragmentación, una visita que desde nuestra propia contemporaneidad sí ha de llevarse a cabo de una manera fragmentada: mediante la cita, ya sea nostálgica o paródica16, de discursos, imágenes o textos del pasado. Éstos fragmentos constituirán una nueva ficción que, incapaz de ostentar una personalidad y coherencia propias, como sí ocurría con esos grandes relatos del pasado, debe recurrir constantemente a los mismos para formular nuevos discursos ${ }^{17}$

Pero si Moulin Rouge puede ser considerada prototipo del pastiche cinematográfico, no lo es únicamente por recurrir sistemáticamente a esa estética de la repetición -ya sea de las fórmulas que caracterizaron al musical en otros tiempos, como de músicas ya creadas y conocidas por todos, o imágenes que ya hemos visto en otras películas y que forman parte ya de nuestro imaginario colectivo-. La hibridación genérica es otra de las estrategias que nuestra película maneja con total maestría, pues, para empezar, se desarrolla en clave de comedia y de drama al mismo tiempo ${ }^{18}$. Así, y siempre en un tono tragicómico, Moulin Rouge combina, junto al drama más desgarrador que supone la muerte de la protagonista, la comedia sofisticada19 -y que no renuncia, por cierto, al famoso "Toque Lubitsch"20_, que caracteriza a la secuencia precedente a Spectacular Spectacular, en la que Satine

\footnotetext{
15 Lyotard defiende esta idea como clave esencial para comprender el advenimiento de esta nueva realidad posmoderna en la que vivimos. Vid. LYOTARD, J. F.: La condición postmoderna. Madrid, Cátedra, 1994 16 Fredic Jameson diferencia entre la cita parodica y la pastichera, propia de un contexto cultural heterogéneo y carente de norma, y que consistiría, básicamente, en una parodia desprovista de sátira e hilaridad, y por tanto, neutra o vacía JAMESON, F. El posmodernismo o la lógica cultural del capitalismo avanzado. Barcelona, Paidós, 1991, págs. 43-44.

17 Javier Maqua sostiene que, en el ámbito del audiovisual, "la ficción ha reventado y, como en una película gore, sus sangrientas piltrafas lo salpican todo". Estas "piltrafas" están no sólo "formadas por paquete heteróclitos de unidades del relato, sino por restos de sus constituyentes: los personajes o héroes de las ficciones fundadoras [...] por todas partes nos encontramos con sus vísceras y retales; un rostro, un gesto, un sombrero, una gabardina, una mano, un garfio, una sonrisa...". MAQUA, J.: "El estado de la ficción: ¿nuevas ficciones audiovisuales?", en AA.VV.: Historia general del cine. El cine en la era del audiovisual, Op. Cit., pág. 218.

18 La introducción del componente dramático en el género, inicialmente conocido como "comedia musical", ya había sido puesto en práctica en célebres películas como Ha nacido una estrella (Star is Born, George Cukor, 1954) West Side Story (Robert Wise y Jerome Robbins, 1961) o la propia Sonrisas y lágrimas.

19 Un estudio sobre la comedia clásica americana en CAVELL, S.: La búsqueda de la felicidad. La comedia de enredo matrimonial en Hollywood. Barcelona, Paidós, 1999.

20 Con este calificativo se alude a la refinada puesta en escena, por parte de este realizador, de situaciones y diálogos "subidos de tono", que no eran mostrados explícitamente, pero sí elegantemente sugeridos mediante elipsis.
} 
y Christian protagonizan un divertido equívoco: Christian sólo quiere recitar un inocente poema para promocionar su obra teatral, pero Satine, al confundirlo con el Duque, desempeña el papel de "ardiente tentadora" que Zidler le ha encomendado. También hay sitio para otra forma de comedia más dinámica y disparatada: el slapstick, o comedia alocada del mudo, basada en el gag visual, y que es la forma en que se desarrolla el desenlace en el escenario, antes de la muerte de Satine.

Incluso podemos afirmar que la película presenta dos clímax correspondientes a cada forma de expresión: el final disparatado con que concluye la gran obra teatral que se ha venido ensayando durante toda la película (que terminará pareciendo un auténtico happening ${ }^{21}$ ), e inmediatamente después, la trágica muerte de Satine. Por otra parte, la puesta en escena de la secuencia del torreón gótico, con un Duque que se parece más que sospechosamente al Conde Drácula, se aproxima bastante a la estética generada por el cine de terror que popularizaran la Universal en los años treinta o la británica Hammer en los cincuenta y sesenta. A esto habría que añadir la estética de videoclip con que se concibe toda la película ${ }^{22}$. E incluso la riqueza escenográfica que presenta el film sugiere cierta afinidad con el gran espectáculo de la ópera, drama decimonónico por excelencia en el que se combinan la exageración, la tragedia y la fuerza inexorable del destino. Finalmente, no debemos olvidar que la película se identifica con una representación teatral por medio de la apertura y cierre de telón con que comienza y termina ${ }^{23}$.

En este sentido, advertimos que el argumento principal presenta la particularidad de desarrollarse al mismo tiempo que el de la obra teatral de Christian que se ensaya en el "Moulin Rouge", estableciéndose entre ambos constantes puntos de contacto: la pieza trata sobre una cortesana india que confunde a un mísero tocador

21 No resultaria descabellado, en este contexto, relacionar esta secuencia, en la que se produce una fuerte interactuación entre el escenario (Satine, Zidler) y la platea (Christian, el Duque y el público), con la escena final de la delirante y no menos "pastichera" The Rocky Horror Picture Show (Jim Sherman, 1975), un film que es célebre, sobre todo, por los improvisados happenings con los que reaccionaban sus admiradores incondicionales cuando acudian a verla a las salas de proyección.

22 No debemos olvidar que Moulin Rouge es un vídeo musical concebido para verse como una película (algo que ya ocurría con El muro (The Wall, 1982) de Alan Parker y Pink Floyd), pero podría verse también en la televisión como un vídeo musical, lo que supone una vuelta de tuerca más en este campo decididamente a televisión como un video musical, lo que supone una vuelta de tuerca mas en este campo decididamente abonado para la interactuación de contaminaciones mutuas. Incluso el discurso de la publicidad puede entrar en este juego combinatorio si en cuenta la gran proximidad entre ésta y el propio videoclip (recordemos, además, que muy recientemente el propio Baz Luhrmann ha dirigido un spot publicitario para Chane con Nicole Kidman como protagonista, y con una estética muy cercana a la de Moulin Rouge).

23 Según Román Gubern, nuestra iconosfera se halla caracterizada por su densidad, heterogeneidad semiótica, diversidad técnica y pluralidad de funciones. En un ámbito cinematográfico o de análisis mediático, estos aspectos se traducen como contaminaciones genéricas, prestamos, hibridación de los sistemas de representación y sincretismo de los discursos. GUBERN, R.: Op. Cit., págs. 296-297.

24 Pero, ¿es la obra la que se parece a la vida de los personajes o la vida de éstos la que se parece a la obra? En Moulin Rouge, la obra teatral de los bohemios no finaliza como debiera, pues las circunstancias precipitan que la cortesana elija al mísero tocador de sitar al revelar Satine, finalmente, la verdad a Christian. 
de sitar con un marajá, enamorándose de él. Descubierta la equivocación, y después de ofrecerle el auténtico marajá todas las riquezas, la cortesana terminará, sin embargo, eligiendo al pobre músico. Este es el argumento que el protagonista idea como vehículo para difundir los ideales de la "revolución bohemia", pero como es lógico, al Duque no le gusta nada, y hará lo imposible por modificar este final al verse identificado con el marajá. Las similitudes de esta historia con las vivencias de los personajes de la película son más que evidentes, y éstos adquieren los roles de los personajes de la obra teatral: Satine confunde al pobre poeta con el Duque, al tiempo que éste intenta hacerse con el amor de la cortesana deslumbrándola con joyas y riqueza; finalmente, y aunque la protagonista tendrá en un principio que mentir a Christian, su verdadera elección recaerá, cómo es lógico, sobre el poeta. La conexión entre las dos líneas de acción es constante (a menudo se refleja en los diálogos entre los personajes, y en sus situaciones) y ambas terminarán confluyendo en el clímax final, donde compartirán un único desenlace, uniéndose ambas tramas ${ }^{24}$.

De este modo, vemos como el film versa sobre una obra teatral, y se identifica, al mismo tiempo, por medio del uso del telón, con una de ellas: si en Historia del Arte usamos la expresión "cuadro dentro del cuadro", o incluso hablamos de "cine dentro del cine", en este caso, y como vuelta de tuerca sobre esta idea, podemos hablar de "teatro dentro del teatro". A la estructura narrativa en la que los personajes representan, dentro del texto, la misma situación que ellos mismos están viviendo, la llama Mijaíl lampolski mise-en-abîme, "construcción en forma de abismo" o "construcción en heráldica" (pues designa, en un escudo, la repetición de ese mismo escudo de forma reducida). Este tipo de recurso, que no es sino una autocita, juega con las ilusiones, las referencias, la intercambiabilidad de los códigos, y supone "una verdadera ilusión de generación de sentido, que siempre acompaña en cierto sentido a la 'representación pura"25.Muchos de estos recursos, específicamente posmodernos, y ejemplificadores de lo que entendemos por intertextualidad ${ }^{26}$, contribuyen a configurar esa éstetica del exceso de la que hace gala nuestra película, y que

Esto demuestra que "...el arte sólo comienza donde termina la imitación, [...] la vida es disolvente que destruye el arte, [...] la vida imita al arte más que el arte a la vida". WILDE, O. (1891): "La decadencia de la mentira", en Intenciones. La Nave, Madrid, 1930, pág. 57.

25 IAMPOLSKI, M.: La teoría de la intertextualidad y el cine. Valencia, Episteme, 1985, págs. 33-46.

26 Procedente de la noción de "dialogismo", definida por Bathkin, el término intertextualidad hace referencia al solapamiento de varias superficies textuales por medio de citas, referencias, confluencias e influencias de otros textos. Julia Kristeva, desde el ámbito de la semiótica, fue la primera en definir el texto como producto o significante y posteriormente, Gérard Genette acuñaría el término transtextualidad para aludir a todo lo que o significante, y posteriormente, Gerard Genette acunaría el témino transtextualidad para aludir a todo lo que pone a un texto en relación con otros. Para una mayor profundización en torno a la teoría de la intertextualidad puede verse STAM, R.; BURGOYNE, R.; FLITTERMAN-LEWIS, S.: Nuevos conceptos de la teoría del cine. Barcelona, Paidós, 1999, págs. 211-250.

27 En este sentido, Moulin Rouge pone en práctica algo que ya se experimentó con la ópera rock Jesucristo Superstar (Jesus Christ Superstar, Norman Jewison, 1973), pero a diferencia de ésta, con música de Andrew Lloyd Webber y letra de Tim Rice, la película de Luhrmann se nutre, para su banda sonora, de grandes éxi- 
puede verificarse en el modo de representar en ella el tiempo y el movimiento (cámara lenta o rápida, la combinación de ambas, el movimiento revertido, la congelación de la imagen), el anacronismo consciente -resultante de combinar un argumento ambientado en las postrimerías del siglo XIX con el lenguaje audiovisual y la música característicos de las postrimerías del $\mathrm{XX}^{27}$-, una cita rebuscada, o la propia combinación de géneros que ya hemos comentado. Otra expresión del exceso y excentricidad de este film se observa en la propia elaboración técnica de la película, totalmente virtuosista: gracias a los efectos especiales, podemos contemplar esos travellings imposibles que nos llevan por todo París, ver como la luna cobra vida, asistir a espectaculares elipsis temporales sin necesidad de recurrir al montaje, o ver como el Hada Verde se escapa de la etiqueta de la botella de absenta y traza en el aire con su vuelo liberty, beauty, freedom y love, el lema de la "revolución bohemia". Es necesario un soporte formal desmesurado para albergar el exceso contenido en Moulin Rouge, donde confluyen de forma natural las poéticas de lo inestable, lo informe, lo caótico, lo irregular y lo accidental.

$Y$ en medio de este alarde de refinamiento y sofisticación, se introducen manifestaciones tradicionalmente encuadradas en el ámbito de la baja cultura y de lo popular, un comportamiento más que lógico en una película totalmente decadente, pero en todo momento consciente de ello. Así, junto al cotidiano lenguaje del videoclip y los grandes éxitos del pop de su banda sonora, Moulin Rouge dedica una atención especial a una de las realidades cinematográficas más tremendamente populares y mediáticas de nuestros días, que además, goza de rabiosa actualidad en Occidente, donde se está poniendo progresivamente de moda: el cine de Bollywood. La obra final de los bohemios, Hindi Sad Diamonds, imita los espectaculares números musicales del cine más comercial de Bombay ${ }^{28}$, a la vez que combina la canción de Marilyn con el tema Chamma Chamma, que pertenece al film "made in Bollywood" China Gate (Rajkumar Santoshi, 1998) ${ }^{29}$.

De este modo, y dado que Moulin Rouge se basa en la desestabilización de una estética clásica, podríamos referirnos a ella con el calificativo de "neobarroca",

tos musicales por todos conocidos, desde el Cancán de Offenbach a Lady Marmelade), y que son readaptados para convertirlos en la expresión alucinada de un espectáculo imposible.

28 Una aproximación al cine de Bollywood, desde sus comienzos en la década de los cincuenta, hasta el momento actual, en ELENA, A.: Los cines periféricos. África, Oriente Medio, India. Barcelona, Paidós, 1999 págs. 99-134.

29 Debemos tener en cuenta que el cine comercial hindú, eminentemente musical, se ha nutrido, desde sus comienzos, del cine clásico de géneros, elaborando a partir del mismo los más elocuentes pastiches. No deja de resultar curioso que una película tan descaradamente pastichera -y también musical- como Moulin Rouge se apropie ahora de la particular estética de las producciones "bollywoodienses" (especialmente de los colores "chillones" que caracterizan a éstas.

30 CALABRESE, O: La era neobarroca, Madrid, Cátedra, 1989.

31 En un ámbito cinematográfico, Carlos Losilla aplica el término "manierismo" (controvertido concepto intro- 
término acuñado por Omar Calabrese para hacer referencia a los productos culturales prototípicos de nuestro gusto contemporáneo ${ }^{30}$, del que Moulin Rouge, con su descarada estética posmoderna, podría ser un paradigmático ejemplo. $Y$ ya que hemos hablado de "neobarroco", podemos considerar una cierta aproximación entre el film de Luhrmann y términos como "manierismo" 1 o "barroquismo", pues Moulin Rouge constituye una metáfora que ilustra el drama de todos aquellos personajes que deben pertenecer forzosamente al mundo viciado y oscuro del local: tras sus brillos, destellos, lujos y fantasías, oculta un mundo poblado de parias y desgraciados de la sociedad, que como la propia Satine, no tienen más destino que el de servir como exótica diversión de una clase social que los ha desheredado y condenado a formar parte de tan miserable existencia. Así, y junto a la gran fuerza sensorial y sugerente del color, que se convierte, como ya comentábamos, en una riquísima fuente de sugerencias, el atrezzo de la película está cargado de objetos que, aisladamente, presentan una importante carga simbólica y un gran poder de evocación ${ }^{32}$.

Destaca así esa pequeña ave exótica enjaulada que aparece discretamente en las estancias ocupadas por Satine, en su camerino y en su alcoba. Este motivo puede pasar totalmente desapercibido, pero si visualizamos la película con atención, podemos ver como aparece casi siempre formando parte de los desordenados y recargados encuadres en los que la protagonista aparece como la figura principal. Se convierte así en el símbolo que mejor expresa el drama de la protagonista: Satine es como ese pajarillo que está condenado a vivir rodeado de una vulgaridad que lo desprecia y humilla, pues su verdadero sueño es ser una auténtica actriz y no una vulgar bailarina de cancán. A menudo manifiesta su deseo de "volar lejos", y al igual que el pájaro, no puede escapar del Moulin Rouge, su jaula de oro. La película hace uso de una bellísima imagen para ilustrar esta analogía: un primer plano del rostro abatido de Satine se dispone justo detrás de la imagen borrosa del pájaro enjaulado; al mismo tiempo, el regente del local anuncia a ésta su enfermedad mortal, que hasta ahora le había sido ocultada, destruyendo brutalmente todos sus deseos y aspiraciones.

Pero otros símbolos, no menos hermosos y de gran fuerza expresiva y sensorial contribuyen a acrecentar esa enorme sofisticación con que está concebida

ducido en España por Jesús González Requena) a los momentos de tensión que, en el ámbito del cine clásico americano de estudios, precedian, de algún modo, a su posterior crisis y definitiva desestabilización. LOSILLA, C.: La invención de Hollywood. O cómo olvidarse de una vez por todas del cine clásico. Barcelona, Paidós, 2003.

32 No olvidemos que Moulin Rouge se inspira en la estética simbolista de Fin de Siglo que, en su afán por trascender la vulgar realidad, hizo uso de un sofisticado sistema de connotaciones veladas en el que se aludía, con imágenes de gran poder sensorial, a otras ideas, realidades o entidades que se hallaban ocultas tras las apariencias. 
toda la pelicula. Uno de ellos es la joya: Satine es el "diamante reluciente" del "Moulin Rouge" y su primera y última aparición en el escenario están marcadas por la relación del personaje con los joyas que porta. El Duque, además, trata en todo momento de hacerse con los favores de la protagonista a cambio de las alhajas que le regala. Las joyas no sólo ilustran ese gusto decadente por la belleza artificial propia de la estética de Fin de Siglo en la que se inspira el film, sino que, paradójicamente, aluden a la miseria y a la pobreza moral que rodea a los personajes esclavizados en el local, que como Satine, pueden ser comprados miserablemente por un burgués adinerado a cambio de aquéllas.

Por otra parte, la identificación de la protagonista con las joyas que luce, contribuye a sugerir como este personaje es concebido de una forma materialista por el Duque o los burgueses que asisten al espectáculo: se encaprichan de ella, igual que pueden verse seducidos por la belleza de las piedras preciosas, y quieren poseerla como si de un objeto de lujo más en sus vidas se tratara.

También las flores son frecuentes en el atrezzo, donde aparecen siempre de forma más bien discreta, pero no por ello poco efectiva. La frescura y la belleza de estas flores remiten de nuevo a la protagonista, que es una vulgar prostituta, pero presenta una gran belleza y entereza moral que la convierten en una criatura delicada y pura, como las flores que casi siempre aparecen en algún lugar de los encuadres que ella protagoniza. El momento de su muerte, además, está presidido por una lluvia de pétalos blancos y rosados que, junto a la fotografía en estos mismos tonos da a la escena un carácter de fuerte melancolía.

Afuera, además, cae una fina y blanca nieve que contribuye a reforzar la idea de pureza de corazón de Satine, que muere como una víctima inocente de un mundo hostil y socialmente degenerado.

Y poco más podemos decir acerca de la magnitud y envergadura de este producto cinematográfico destinado al entretenimiento y al más puro goce de nuestros sentidos: su luz y color nos embarga, su ritmo nos hipnotiza, su música nos conmueve y sus imágenes nos traen hermosos recuerdos. Todo en Moulin Rouge está milimétricamente calculado para convertirnos en sus cómplices más fieles, y para ello no duda en mezclar discursos o géneros, en combinar melodías, en destruir las leyes de la lógica espacio-temporal ni en echar mano de motivos procedentes de la más absoluta cotidianeidad para rodearlos de la más elevada sofisticación. No le importa exagerar ni parecer inverosímil, como tampoco le importa ser descaradamente superficial.

$Y$ es que, como producto prototípico de una sensibilidad específicamente posmoderna, y fruto de los presupuestos estéticos de nuestra propia cultura contemporánea, Moulin Rouge tan sólo busca nuestro deleite sensorial, el mero disfrute de nuetra mirada, y la complicidad de nuestros sentimientos. No tiene más sentido que 
Q a a tículos Un ejemplo de postmodernidad cinematográfica...

el de su propia existencia como sofisticado divertimento, como -ya lo comentábamos- juguete caro. Y no alberga más pretensión que la de contarnos, por medio de un soporte formal absolutamente desmesurado, una simple historia. "Una historia sobre la libertad, la belleza y la verdad, pero por encima de todo: una historia sobre el amor". 
